MLC concentrations will be useful in the assessment of such a response remains to be determined. A previous preliminary report revealed high MLC levels in $75 \%$ of patients with myositis, ${ }^{8}$ but a correlation with disease activity was not performed. Further prospective longitudinal studies are in progress to determine the utility of measuring MLC concentrations in myositis.

REUVEN MADER RACHEL PAUZNER EDWARD C KEYSTONE Division of Rheumatology, Department of Medicine, The Wellesley Hospital, University of Toronto, Toronto, Ontario

PHILLIP D NICOL VARUN J SEHGAL JEAN J TURLEY Department of Medicine

Correspondence to: Dr E C Keystone, Room 655, Turner Wing, Rheumatic Disease Unit, The Wellesley Hospital, 160 Wellesley Street East, Toronto, Ontario M4Y 1J3, Canada.

1 Khaw B A, Gold H K, Fallon J T, Haber E. Detection of serum cardiac myosin light chains in acute experimental myocardial infarction: radioimmunoassay of cardiac myosin

2 Trahern C A, Gere J B, Krauth G H, Bigham D A. Clinical assessment of serum myosin light chains in the diagnosis of acute myosin light chains in the diagnosis of acute myocardial

3 Katus H A, Yasuda T, Gold H K, et al. Diagnosis of acute myocardial infarction by detection of circulating cardiac myosin ligh chains. Am f Cardiol 1984; 54: 964-70.

4 Isobe $M$, Nagai $R$, Ueda $S$, et al. Quantitative relationship between left ventricular function and serum cardiac myosin light chain 1 levels after coronary reperfusion in patients with acute myocardial infarction. Circulation 1987; 76: $1251-61$.

5 Bohan A, Peter J B. Polymyositis and dermatomyositis. $N$ Engl $₹$ Med 1975; 292: 344-7.

6 Helewa A, Goldsmith C H, Smythe H A. The modified sphygmomanometer-an instrument to measure muscle strength: validation study. $\mathcal{F}$ Chronic Dis 1981; 34 353-61.

7 Nicol P D, Matsueda G R, Haber E, Khaw B A. Cardiac myosin light chain specific, peptide based, single monoclonal radioimmunoassay for the detection of myocyte necrosis. Circulation 1989; 80: 355 .

8 Tanaka M, Kobayashi S, Tamura N, Hashimoto H, Hirose S. Cardiac involvement detected by serum myosin light chain 1 in patients with poly/dermatomyositis. Arthritis patients with poly/derma
Rheum 1991; 43: 149 .

\section{Decreased triglyceride levels with low calorie diet and increased renal excretion of uric acid in hyperuricaemic- hyperlipidaemic patients}

While the association between hyperuricaemia and hyperlipidaemia is well known, it has so far been poorly explained. ${ }^{1}$ The presence of external factors such as obesity, increased alcohol intake, ${ }^{2}$ or some nutritional habits $^{3}$ in the same individual was initially believed to cause both metabolic disturbances. However, this has been shown not to be the case in many instances; hyperuricaemia and hyperlipidaemia have been observed in the absence of those factors, ${ }^{4}$ and even been ascribed to a common genetic basis. $^{5}$ In addition, hyperuricaemic-hyperlipidaemic patients have been shown to exhibit decreased renal excretion of urate relative to hyperuricaemic-normolipidaemic individuals. ${ }^{6}$

Metabolic parameters and renal excretion of urates for the two patient groups before (A) and after (B) low calorie dieting

\begin{tabular}{lcccc}
\hline & Group $I$ & Group II & Group $I$ & Group II \\
& $A$ & $A$ & $B$ & $B$ \\
\hline Body mass index & $30 \cdot 1(3 \cdot 5)$ & $29 \cdot 8(3 \cdot 6)$ & $28 \cdot 7(3 \cdot 4)^{\star \star \star}$ & $28 \cdot 2(3 \cdot 2)^{\star \star}$ \\
Serum uric acid (mg/dl) & $8 \cdot 3(1 \cdot 6)$ & $8 \cdot 4(1 \cdot 6)$ & $8 \cdot 0(1 \cdot 6)$ & $7 \cdot 5(1 \cdot 5)$ \\
Total cholesterol (mg/dl) & $192(24 \cdot 2)$ & $261 \cdot 3(40 \cdot 9) \dagger$ & $173 \cdot 5(33 \cdot 6)^{\star}$ & $204 \cdot 1(41 \cdot 0)^{\star \star \star} \dagger$ \\
Total triglycerides (mg/dl) & $133(44 \cdot 8)$ & $278(53 \cdot 3)+t \dagger$ & $90 \cdot 3(42 \cdot 5)^{\star \star}$ & $161 \cdot 5(117)^{\star \star \star} \dagger$ \\
Uric acid excretion (mg/24 h) & $621(215)$ & $605(194)$ & $629(347)$ & $715(157)^{\star}$ \\
Fractional excretion uric acid (\%) & $5 \cdot 8(1 \cdot 4)$ & $6 \cdot 0(2 \cdot 5)$ & $6 \cdot 2(2 \cdot 5)$ & $8 \cdot 2(3 \cdot 2)^{\star} \dagger$ \\
\hline
\end{tabular}

Values are mean (SD). Group I= primary hyperuricaemic; group II = primary hyperuricaemichyperlipidaemic. Significant differences: ${ }^{\star} p<0.05,{ }^{\star \star} p<0.01,{ }^{\star \star \star} p<0.001$ for comparison of A with $B$ $t \mathrm{p}<0.05, \mathrm{ttp}<0.01, \mathrm{tt} \mathrm{p}<0.001$ for comparison of group I with group II.

In order to investigate alterations in the renal excretion of uric acid in relation to plasma concentrations of triglycerides, we carried out a dietary intervention study in hyperuricaemic patients who were placed on a controlled low calorie regimen intended to decrease their triglyceride concentrations.

We studied 15 primary hyperuricaemic patients (all men) (group I) and 15 primary hyperuricaemic-hyperlipidaemic patients (all men) (group II). Subjects with plasma uric acid concentrations greater than $7 \mathrm{mg} / \mathrm{dl}$ were classed as hyperuricaemic, and those with values greater than $200 \mathrm{mg} / \mathrm{dl},^{7}$ as hyperlipidaemic. All were subjected to an initial basal analytical determination for uric acid, total triglycerides, total cholesterol, and uric acid clearance and fractional excretion after three days on a low purine diet, ${ }^{8}$ followed by a second determination after three weeks on a low calorie diet (1200 kcal per day: carbohydrate $=50 \%$; protein $=20 \%$; lipid $=$ $30 \%$ ) with alcohol excluded. Three days after the second determination, patients were again placed on a low purine diet similar to that used before the first determination.

The Wilcoxon test was used to evaluate the significance of differences between the means in the two patient groups before and after low calorie dieting. Statistically significant difference between the two groups was calculated by the Mann-Whitney test.

The table shows the results. All the patients lost a significant amount of body weight on dieting, regardless of the group to which they belonged, but uric acid levels did not change in either group as a result of dieting.

Patients in group II (hyperuricaemichyperlipidaemic) exhibited considerably decreased triglyceride and cholesterol concentrations after the low calorie diets, concomitant with increased renal excretion of uric acid, which was not observed in group I.

Our results support the hypothesis that the association between triglyceride concentration and renal excretion of uric acid is more than a casual relationship; by decreasing triglyceride concentrations, we succeeded in increasing renal uric acid excretion without pharmacological intervention, while controlling the purine intake during assessment of the renal excretion of uric acid. In our opinion, the relationship is particularly valid in hyperuricaemic-hyperlipidaemic patients, as the decrease in the triglyceride concentrations and weights of the hyperuricaemicnormolipidaemic men (group I) was not accompanied by increased renal excretion of uric acid. Collantes et $a l^{6}$ also found that renal excretion of urate was less in hyperuricaemic-hyperlipidaemic patients than in hyperuricaemic-normolipidaemic patients. Acute increase in serum triglyceride concentrations has been shown not to modify uric acid synthesis or excretion. ${ }^{39}$ However, these data are not conclusive, as ingested triglycerides have a different composition and metabolic origin than endogenous triglycerides.

Other authors have shown an inverse correlation between insulin sensitivity and uric acid concentration, ${ }^{10}$ and between insulin resistance and clearance of uric acid from healthy volunteers. ${ }^{11}$ The potential link between the inverse relationship of the renal excretion of uric acid with hyperinsulinism and our findings remains to be determined The mechanisms responsible for such an inverse relationship between renal excretion of uric acid and triglyceride concentrations will probably be elucidated as knowledge of the metabolic syndrome expands.

F J TINAHONES
F J C-SORIGUER
Sección de Endocrinologia,
H Carlos Haya de Málaga,
Málaga, Spain
E COLLANTES
G PÉREZ-LINDÓN
P SÁNCHEZ GUIJO
Dpto Medicina,
U D Patologia General y Propedéutica Clinica,
Facultad de Medicina de Córdoba,
Córdoba, Spain
J A LILLO
Servicio de Bioquimica,
H Velez, Málaga, Spain

Correspondence to: Dr F J Tinahones Madueño, C Ayala $n^{\circ} 284^{2}$ Esc $6^{\circ}$ A, Málaga, Spain 29002.

1 Palella T D, Fox I H. Hyperuricaemia and gout. In: Scriver C H R, Baudet A L, Sly W S, Valle $\mathrm{D}$, eds. The metabolic basis of inherited diseases. New York: MacGraw-Hill, 1989; 965-1006.

2 Jiao S, Kameda K, Matsuzawa Y, Tauri S. Hyperlipoproteinaemia in primary gout: hyperlipoproteinaemic phenotype and influence of alcohol intake and obesity in Japan. Ann Rheum Dis 1986; 45: 308-12.

3 Fox H I, John D, DeBruyne S, Dwosh I, Marliss E B. Hyperuricemia and hypertriglyceridemia: metabolic basis for the association. Metabolism 1985; 34: 741-6.

4 Collantes E, Pineda M, Añón J, Sánchez $P$ Hyperuricemia-hyperlipemia association in the absence of obesity and alcohol abuse. Clin Rheumatol 1990; 9: 28-31.

5 Ferns G A, Lanham J, Galton D J. The association between primary gout and hypertriglyceridemia may be due to genetic linkage. Monogr Atheroscler 1985; 13: 121-4.

6 Collantes E, Tinahones F J, González A, Añón J, Pineda M, Sánchez P. Renal excretion of urate by hyperuricaemic-hyperlipidemic patients. Clin Rheumatol 1992; 11: 498-501.

7 International Taskforce for the Prevention of Coronary Heart Disease. Prevention of coronary heart disease. Scientific background and new clinical guidelines. Nutr Met Card Dis and new clinical guid

8 Emmerson B T. Identification of the causes of persistent hyperuricaemia. Lancet 1991; 337 1461-3.

9 Gibson T, Kilbourn K, Horner I, Simmonds H A. Mechanism and treatment of hypertriglyceridaemia in gout. Ann Rheum Dis 1979, 38: $31-5$. 
10 Vuorinen-Markkola H, Yki-Järvinen H. Hyperuricemia and insulin resistance. 7 Clin Endouricemia and insulin resista

11 Facchini F, Chen I, Hollenbeck CB, Reaven GM. Relationship between resistance to insulin-mediated glucose uptake, urinary uric acid clearance, and plasma uric acid concentration. $\mathscr{f} A M A$ 1991; 266: 3008-11.

\section{Serum levels of interleukin-8 in patients with Behçet's disease}

Interleukin-8 (IL-8) or neutrophil activating peptide-1 (NAP-1) is produced by a variety of cell types including endothelial cells, synovial cells, keratinocytes, fibroblasts, and monocytes-macrophages. ${ }^{1-4}$ IL- 8 has been shown to induce neutrophil degranulation and to be a potent chemoattractant for neutrophils. ${ }^{25}$ Furthermore, IL-8 activated neutrophils are a major source of the enzymes involved in tissue destruction. ${ }^{5}$

Behçet's disease (BD) is an inflammatory vasculitis of unknown cause characterised by orogenital ulceration and variably associated with uveitis, arthritis, and skin lesions. ${ }^{6}$ In addition to the migration and activation of mononuclear cells, a neutrophilic vascular reaction was reported to be the fundamental histological change in certain lesions of $\mathrm{BD} .^{78}$ For this reason, we studied the serum levels of IL-8 in patients with BD and healthy controls, and the possible relationship with disease activity in BD

Forty patients with $\mathrm{BD}$, all fulfilling the International Study Group criteria for the diagnosis of $\mathrm{BD}^{9}$ and 25 apparently healthy controls were studied. At the time of the blood withdrawal, 20 patients (12 men, eight women; mean age 36.4 (SD 7) years, range 25-54) having at least two of the following were considered as having active disease: oral ulcer, genital ulcer, eye lesions, skin lesions, arthritis, pulmonary involvement and vascular lesions (venous thrombosis, arterial aneurysm) and 20 patients (14 men, six women; mean age $37.5(8.6)$ years, range 22-54) showing no clinical or laboratory disorder related with $\mathrm{BD}$ for at least one month were considered as having inactive disease. All but three patients with active disease were receiving colchicine $1-1.5 \mathrm{mg} /$ day. Patients with inactive disease were receiving low-dose colchicine $(0.5-1.0 \mathrm{mg} /$ day). Sera were stored at $-70^{\circ} \mathrm{C}$ until required for use.

Serum IL- 8 was determined by Biotrak Interleukin-8, human enzyme linked immunosorbent assay system kit (Amersham), which uses the quantitative immunometric, sandwich enzyme immunoassay technique. All samples were tested in duplicate. Intra-assay and inter-assay variation for this kit were $7.5 \%$ and $9 \cdot 1 \%$, respectively, and the lower limit of detection of IL- 8 was $18 \cdot 1 \mathrm{pg} / \mathrm{ml}$.

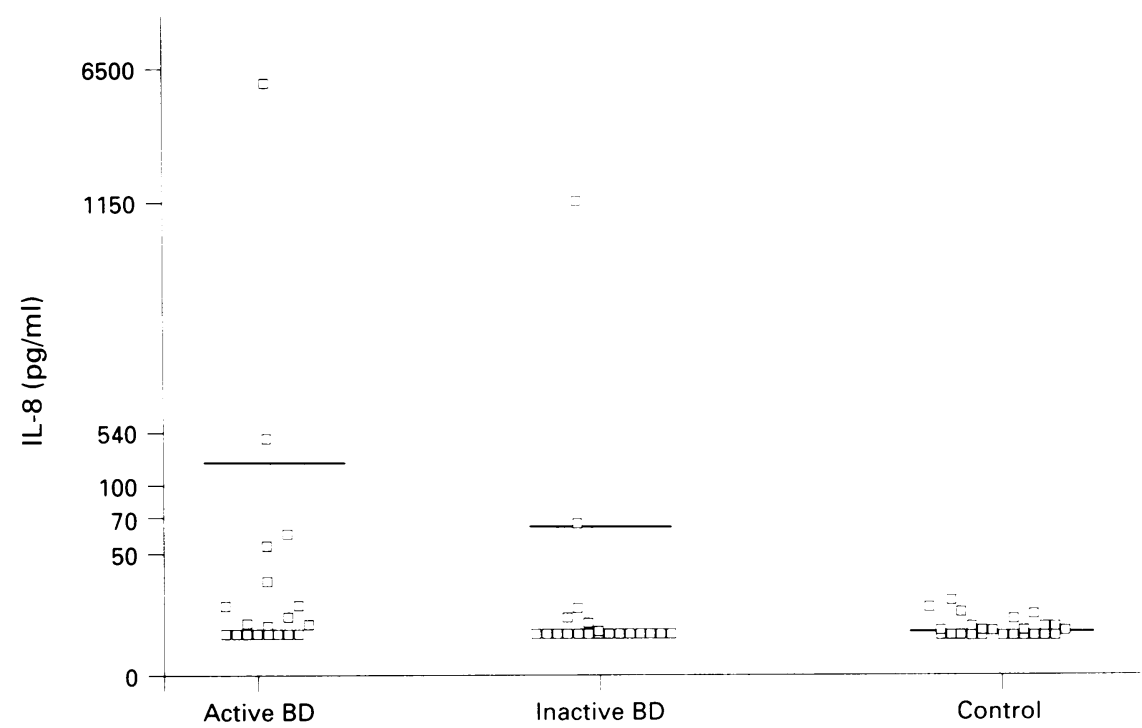

Serum interleukin-8 (IL-8) levels in patients with Behçet's disease (BD) and healthy controls.

Erythrocyte sedimentation rate (ESR) was determined by the Westergren method and C reactive protein $(C R P)$ by nephelometry (Behring). The IL-8 data were logarithmically transformed before statistical analysis and groups were compared by Student's $t$ test and correlation analysis.

The mean (SD) IL-8 concentration was $369.3(1447.8) \mathrm{pg} / \mathrm{ml}$ in patients with active $\mathrm{BD}, 65.6(255.8) \mathrm{pg} / \mathrm{ml}$ in patients with inactive disease, and $13 \cdot 1(12 \cdot 3) \mathrm{pg} / \mathrm{ml}$ in healthy controls (figure). Although the mean IL-8 values in active and inactive $B D$ appeared higher than those in the control group, the difference not statistically significant $(p>0.05)$. Mean serum IL-8 levels of patients with active $\mathrm{BD}$ were greater than those of patients with inactive $\mathrm{BD}$, but the difference was again statistically insignificant $(\mathrm{p}>0 \cdot 05)$. Clinical disease activity correlated well with both ESR and CRP ( $r=0.665$, $\mathrm{p}<0.001)$, but there was no correlation of IL-8 with ESR or CRP ( $p>0.05$ ).

In conclusion, the serum level of IL- 8 in $\mathrm{BD}$ patients was not significantly different from that in healthy controls. Further studies are needed to define the specific function of this cytokine in BD, and IL-8 studies in tissue samples may provide useful information concerning the aetiopathogenesis of $\mathrm{BD}$.

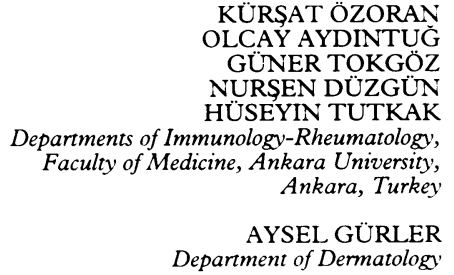

1 Thornton A J, Strieter R, Lindley I, Baggiolini M, Kunkel S L. Cytokine induced gene expression of neutrophil chemotactic factor/interleukin- 8 in human hepatocytes. f Immunol 1990; 144: 2600-13.

2 Matsumoto T, Miike T, Nelson R P, Trudeau W L, Lockey R F, Yodoi J. Elevated serum levels of IL-8 in patients with HIV infection. Clin Exp Immunol 1993; 93: infection.

3 Deleuran B, Lemche $P$, Kristensen $M$, et al. Localisation of IL-8 in the sinovia membrane, cartilage-pannus junction and chondrocytes in rheumatoid arthritis. Scand $\mathcal{F}$ Rheumatol 1994; 23: 2-7.

4 Brennan F M, Zachariae C O C, Chantry D et al. Detection of interleukin 8 biological activity in synovial fluids from patients with rheumatoid arthritis and production of interleukin $8 \mathrm{mRNA}$ by isolated synovial cells. Eur Immunol 1990; 20: 2141-4.

5 Peichl P, Ceska M, Broell $\mathrm{H}$, Effenberger $\mathrm{F}$ Lindley I J D. Human neutrophil activating peptide/interleukin 8 acts as an autoantigen in rheumatoid arthritis. Ann Rheum Dis 1992; 51: $19-22$

6 Hamzaoui K, Ayed K, Slim A, Hamza M Touraine J. Natural killer cell activity, interferon gamma and antibodies to herpes viruses in patients with Behçet's disease. Clin Exp Immunol 1990; 79: 28-34.

7 Gilhar A, Wintwrstein G, Turani H, Landau J, Etzioni A. Skin hyperactivity response (pathergy) in Behcet's disease. $7 \mathrm{Am} A c a d$ Dermatol 1989; 21: 547-52.

8 Helm T N, Camisa C, Allen C, Lowder C. Clinical features of Behçet's disease. Oral Surg Oral Med Oral Pathol 1991; 72: 30-4.

9 International Study Group (ISG) for Behçet's Disease. Evaluation of diagnostic criteria in Behçet's Disease. Br $\mathcal{F}$ Rheumatol 1992; 31 299-308. 